\title{
Den yderste højrefløj - tunge ledsætninger og andre utilpassede elementer i sætningsperiferien
}

\section{Sune Sønderberg Mortensen}

This study explores the constituent order of the right periphery of Danish sentences in modern spoken and written discourse. While it is commonly held that final nominal clauses, due to weight, are positioned 'outside' the sentence, very few studies have discussed exactly where this outside position is located in relation to other right peripheral constituents. By discussing traditional accounts and criteria, it is shown that the position in question may be said to harbour not only nominal clauses and so-called 'heavy constituents' but a range of subclause types not previously associated with this position. Finally, the topology of extraposition (right-dislocation) and interjectionals are examined and incorporated in a suggested addition to the Danish sentence scheme's right periphery.

Nøgleord: sætningsskema, topologi, ledsætning, tungtled, ekstraposition, interjektional

\section{Indledning}

Forskning, lærebøger og undervisning i dansk grammatik har længe været optaget af hvordan topologien i helsætninger og ledsætninger kan beskrives stadig mere præcist (Diderichsen 1946; Hansen 1970; Heltoft 1986, 1990; Hansen 2007; Hansen \& Heltoft 2011; Jensen \& Christensen 2013). Kombinationen af helsætning og ledsætning er der til gengæld gjort relativt lidt ud af topologisk - især kontekster hvor ledsætningen optræder til sidst. Hansen (1970) viste ved hjælp af maksimaludfyldningsprøver at slutstillede objektledsætninger og at-infinitiver normalt ikke, som andre objekter, har deres placering på det traditionelle skemas nominalplads $(\mathrm{N})$, men grundet vægtforhold 
ude på den anden side af A-pladsen (her illustreret med Hansens komplette skema, jf. fx Hansen 2007):

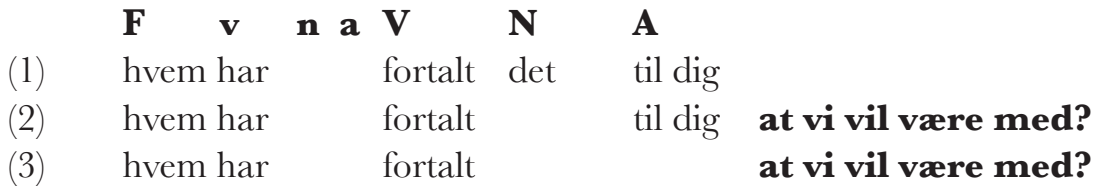
(Hansen 1970: 120)

Så vidt er også moderne grammatikker nogenlunde enige, i det omfang de behandler problemstillingen. Men hvor ledsætningerne og at-infinitiverne så mere nøjagtigt hører til i oversætningen, er der delte meninger om. Hansen placerer dem i "ekstraposition" (Hansen 1970: 120, 2007: 76), mens de i andre fremstillinger fx står i "tungtledsposition" (Christensen \& Christensen 2014: 216), deler plads med frie adverbialer (Becker-Christensen 2010: 131), eller mindre specifikt har "tungtledsplacering [...] uden for satningens normale granser" (Hansen \& Heltoft 2011: 1641). Som jeg kommer nærmere ind på, er der altså ret forskellige analyser på markedet, som i øvrigt alle må siges at medføre nye beskrivelsesproblemer. Hvad gør vi fx med andre ledsætninger der måtte komme bagefter, som i (4) nedenfor - er de automatisk også tungtledsplacerede/ ekstraponerede, eller er der brug for nye pladser i (eller uden for) skemaet?

$$
\begin{array}{llllll}
\mathbf{F} \quad \mathbf{v} & \mathbf{n} \text { a } & \mathbf{V} & \mathbf{N} \text { A } & \text { tungtl./ekstrapos.? } & \text { ?? } \\
\text { Søren har } & \text { fortalt } & & \text { at vi vil være med } & \text { selvom han } \\
& & & \begin{array}{l}
\text { lovede at tie } \\
\text { stille }
\end{array}
\end{array}
$$

Målet med denne artikel er at komme nærmere en kortlægning af de topologiske muligheder for finale ledsætninger og at-infinitiver i deres oversætning. Deres placering må naturligvis forstås i direkte relation til de pladser der omgiver dem, og derfor finder jeg det oplagt at brede perspektivet ud til samtlige de finale pladser og elementer der ofte karakteriseres som placeret uden for sætningen, eller på grænsen, nemlig ekstraposition, interjektionalposition, tungtled og altså finale ledsætninger og at-infinitiver. Jeg vil give et bud på en beskrivelse af deres samspil og argumentere for at sætningens 'yderste højrefløj' faktisk har en topologisk struktur som er meningsfuld at forsøge at indfange, ikke bare for fuldstændighedens skyld, men også fordi placeringsmulighederne 
reflekterer og tydeliggør centrale semantiske og funktionelle egenskaber ved de pågældende elementer.

Først illustrerer jeg nærmere hvordan tungtledsreglen komplicerer beskrivelsen af finale ledsætningers og at-infinitivers placering i deres oversætnings skema. I afsnit 3 diskuterer jeg traditionelle og nyere forsøg på at redegøre topologisk for tungtledsplaceringen, og endelig inddrager jeg i afsnit $4 \mathrm{de} ø \mathrm{v}-$ rige rækkefølgerelationer på den yderste højrefløj i en samlet topologisk skitse.

\section{Tungtledsplacering - en regelmassig uregelmas- sighed}

Som følge af vagtprincippet (Diderichsen 1946; Hansen 2007; Becker-Christensen 2010; Hansen \& Heltoft 2011) har særligt omfangsrige led tendens til at stå så sent som muligt i sætningen, hvilket for tunge nominale og attributive led ofte involverer tungtledsplacering. ${ }^{1}$ Tungtledsplacering er en afvigelse fra normal ledstilling idet det tunge led, eller den tunge del af et led, placeres efter eventuelle prædikativer eller middelbare eller frie led, som normalt optræder sidst i sætningen, fx:

(5a) Lidt efter var (der) forsamlet i den store Sal en talrig Skare af Generaler og højtstaaende Embedsmænd

(Diderichsen 1957: 194)

(6a) der var en lov til debat om de ikke-faglærtes uddannelse (Hansen 2007: 65)

Til sammenligning uden tungtledsplacering:

(5b) Lidt efter var en talrig Skare af Generaler og højtstaaende Embedsmand forsamlet i den store Sal

(6b) der var en lov om de ikke-faglærtes uddannelse til debat

1 Jeg bruger foreløbig Hansen \& Heltofts generelle betegnelse, jf. afsnit 1, som har den fordel at den ikke på forhånd antager en bestemt topologisk status (såsom plads, position eller felt) for placeringen. 


\subsection{Nominale ledsatninger og at-infinitiver som tungtled}

Som det bliver observeret i mange fremstillinger, ses tungtledsplacering i udpræget omfang ved nominale ledsætninger og at-infinitiver (Hansen 1970: 119; Mikkelsen 1975: 646; Diderichsen 1957: 194; Becker-Christensen 2010: 130; Hansen \& Heltoft 2011: 1641; Christensen \& Christensen 2014: 216), fx:

(7) Han udtalte som sin fulde overbevisning, at konen var uskyldig (Mikkelsen 1975: 646)

(8) vi overlader til dig at finde en afgørelse (Hansen \& Heltoft 2011: 1644)

(9) det er nemmere at tage toget (Becker-Christensen 2010: 130)

(10) det gjorde ham ked af det at det gik så dårligt $\mathbf{t}^{2}$ (Becker-Christensen 2010: 130)

Det er værd at understrege at tendensen til tungtledsplacering gælder nominale ledsætninger som sådan, og altså ikke bare at-ledsætninger, fx:

(11a) fortæl mig med det samme om jeg har misforstået noget

(12a) de opdager med det samme hvis man prøver at flygte

(13a) du må gøre med mig hvad du vil

Hansen (1970) peger på at denne analyse må gennemføres konsistent også når lokaliseringsfeltet og andre finale pladser er tomme: "Ud fra disse sikre eksempler bor man vel generalisere til de tilfalde hoor placeringen ikke kan afgores..." (Hansen 1970: 120). Ud fra dette maksimaludfyldningsprincip har vi altså også tungtledsplacering af ledsætningerne i fx:

\section{(1 1b) fortæl mig (Ø) om jeg har misforstået noget \\ $(12 \mathrm{~b})$ de opdager $(\varnothing)$ hvis man prøver at flygte \\ (13b) du må gøre (Ø) hvad du vil}

2 Traditionen behandler gerne subjektledsætningen i denne type konstruktion som ekstraponeret (fx Diderichsen 1957: 174), men Hansen \& Heltoft argumenterer overbevisende for at der ikke er tale om ekstraposition (2011: 1839) - det vender jeg tilbage til i afsnit 3.1. 


\subsection{Attributive og adverbielle ledsatninger som tungtled}

Endvidere finder vi i flere fremstillinger eksempler på at sætningsformede adled kan tungtledsplaceres:

(14) han måtte overdrage den mand magten som han havde regnet for den mest uegnede hertil

(Hansen \& Heltoft 2011: 1642)

(15) I går lukkede vi den flaske vin op som vi fik af min mormor (Jørgensen 2000: 103)

Hvis også sådanne konstruktioner skal underlægges Hansens maksimaludfyldningsprincip, må relativsætningerne beskrives som værende tungtledsplacerede selv når pladserne der entydigt kan vise det, er tomme, sml.:

(16a) I dag har hun købt den cykel til mig som vi kiggede på i weekenden

(16b) ? I dag har hun købt den cykel som vi kiggede på i weekenden til mig

(16c) I dag har hun købt den cykel (Ø) som vi kiggede på i weekenden

Uden det middelbare led til mig er det selvfølgelig ikke muligt at afgøre hvorvidt det 'mangler' foran eller efter relativsætningen, men analysen viser at der i hvert fald er en plads til det foran - og i henhold til vægtprincippet er denne placering en rimelig defaultlæsning. Fører vi tankegangen til ende, bliver resultatet at alle relative såvel som nominale ledsætninger (samt at-infinitiver) der optræder til sidst i deres oversætning, faktisk må stå uden for sætningsskemaet som tungtled når ikke andet er angivet, fx:

\section{Sætningsskema}

(17) Mads fortalte (til mig/Ø)

(18) Så du ham (for lidt siden/Ø)

(19) Ved du (med sikkerhed/Ø)
Tungtled / uden for sætningsskema

at han er blevet skilt

der stod og tissede?

hvor kaffefiltrene er? 
Det kan forekomme overraskende - og fremgår heller ikke af grammatiske lærebøger - at finale relativsætninger således skulle være tungtledsplacerede som udgangspunkt. ${ }^{3}$ Endnu længere væk fra standardeksemplerne kommer vi når der optræder adverbielle ledsætninger og andre adverbielle størrelser efter den tunge ledsætning (på samme hierarkiske niveau):

\section{Sætningsskema}

(20) Mads fortalte (til mig/Ø)

(21) Så du ham (for lidt siden/Ø)

(22) Ved du (med sikkerhed/Ø)

(23) Jeg antog (i lang tid/Ø)

(24) Det stod klart (for mig/Ø)

\section{Tungtled / uden for} sætningsskema

at han er blevet skilt, før jeg nåede at spørge

der stod og tissede, om jeg må spørge?

hvor kaffefiltrene er, nu hvor jeg

\section{har dig?}

at hun boede hjemme, hvilket

var en fejl

at hun var døv, den næste dag

For så vidt at tungtledsplaceringen hører til uden for det regulære sætningsskema, må ethvert efterfølgende element automatisk også stå udenfor, som illustreret ovenfor. Således fremstår tungtledsplacering langt hen ad vejen som en mekanisk regel snarere end en sprogligt bestemt særplacering, og dermed er sætningsskemaet efterladt med en topologisk restkategori hvis udfyldningsmuligheder er vanskelige at definere. Desuden er dens placering i forhold til det øvrige sætningsskema som nævnt heller ikke entydigt beskrevet, hvilket jeg ser nærmere på i det følgende.

\section{Tungtleddenes placering - tidligere fremstillinger 3.1. Tungtledsplacering som ekstraposition}

Diderichsen (1957) karakteriserer tungtledsplacering således:

3 Denne analyse modsiger den slidstærke parole der går på at sætningsleddene 'flytter samlet' (Hansen 2007: 59; Hansen \& Heltoft 2011: 99). Af andre undtagelser fra denne grundregel kan fremhæes middelbare led, der ofte kan opsplittes topologisk i præposition og styrelse (Hansen 2007: 61), fx: De måtte vente $i$ årevis på at han blev fanget vs. At han blev fanget, måtte de vente $i$ årevis på vs. De måtte vente $\boldsymbol{p a} i$ arrevis at han blev fanget. 
Meget omfangsrige Led (specielt Ledsætninger) staar ofte længere tilbage i Indholdsfeltet, end de efter deres Funktion skulde; navnlig staar en Objektsætning næsten altid efter Indholdsadverbialerne. (Diderichsen 1957: 194)

I Diderichsens sætningsskema er der imidlertid ikke flere pladser at gøre godt med efter pladsen til indholdsadverbialerne. Han fortsætter dog umiddelbart herpå med en beskrivelse af "Led uden for Satningsskemaet ("i Ekstraposition")" (Diderichsen 1957: 194) og definerer på den måde indirekte ekstraposition som en multifunktionel plads der kan huse alt hvad der står til højre for indholdsadverbialerne. Herfra er der ikke langt til den analyse Hansen (1970) præsenterer, hvor han antager at positionen til højre for den finale adverbialplads må være ekstraposition (Hansen 1970: 119). Hans konklusion at objektledsætninger og at-infinitiver derfor hører til i ekstraposition, er videreført også i flere nyere fremstillinger (Jørgensen 2000: 102; Jensen 2003: 95; Hansen 2007: 76). Der er i øvrigt også en vis tradition for tilsvarende at analysere særplacerede subjektledsætninger og -at-infinitiver (med funktion som reelle subjekter) som ekstraponerede, fx:

(25) Det var dejligt at du kunne

\section{komme}

(ledsætning i ekstraposition)

(26) Det gjorde godt at få en bajer (at-infinitiv i ekstraposition) (Jørgensen 2000: 102)

Hansen \& Heltoft gør imidlertid op med denne analysepraksis og påpeger at sådanne særplacerede at-infinitiver og ledsætninger i subjektsfunktion (i Hansen \& Heltofts terminologi “eksplikatkonstruktioner") bygger på en rent kataforisk relation i modsætning til ekstrapositionskonstruktioner, sml. fx:

(27a) det er farligt at gå over sporet

(27b) dét er farligt, at gå over sporet (Hansen \& Heltoft 2011: 1839) (at-infinitiv som reelt subjekt)

(at-infinitiv i ekstraposition)

Jeg tilslutter mig dette synspunkt, at ekstrapositionsbegrebet bør reserveres til konstruktioner hvor antecedenten inden for sætningen er "repræsenteret" (Hansen \& Heltoft 2011: 333; se også Diderichsen 1957: 194 og Kristensen 
2007: 7) snarere end eksplikeret eller konstitueret af det særplacerede led, og at tungtledsplacering således ikke bør sammenblandes med ekstraponering.

\subsection{Tungtledsplacering som position $i$ satningsskemaet}

Christensen \& Christensen (2014) opererer i deres sætningsskema med en decideret tungtledsposition:

Her finder vi typisk infinitivsyntagmer og nominale ledsætninger, som har funktion som objekt eller reelt subjekt. Også lange prædikative led kan stå i tungtledspositionen. (Christensen \& Christensen 2014: 216)

Tungtledspositionen (T) findes umiddelbart til venstre for hvad Christensen \& Christensen kalder "ekstra slutfelt" (ES), et felt der tilsyneladende huser ekstraponerede led, kommentarledsætninger og parentetiske størrelser: "Dette led placerer sig efter alle andre satningsled, også efter en eventuel tungtledsposition." (Christensen \& Christensen 2014: 218). De opstiller dette udvidede sætningsskema således:

\begin{tabular}{|c|c|c|c|c|c|c|c|c|}
\hline Forfelt & Centr: & & & Slut & & & & ES \\
\hline & $\mathrm{v}$ & $\mathrm{n}$ & $\mathrm{a}$ & V & $\mathrm{N}$ & A & $\mathrm{T}$ & \\
\hline Preben & sagde & - & & & & til mig, & $\begin{array}{l}\text { at skolen } \\
\text { var lukket, }\end{array}$ & den løgner. \\
\hline Det & er & - & & & svært & $\begin{array}{l}\text { for } \\
\text { ham }\end{array}$ & at danse, & $\begin{array}{l}\text { ham med } \\
\text { krykken. }\end{array}$ \\
\hline
\end{tabular}

Figur 1. Tungtledsposition og ekstra slutfelt hos Christensen \& Christensen (2014: 219).

At Christensen \& Christensen således placerer tungtleddene inden for sætningens grænser, virker umiddelbart appellerende, al den stund at leddene nu engang er del af sætningens propositionelle indhold. Imidlertid er det nemt at finde eksempler på ekstraponerede led som kommer før tungtleddet, fx:

(28a) Min mor fortalte os mange historier om nisser, og de var så livagtige, de historier, at min bror og jeg troede på nisser helt indtil vi skulle konfirmeres... (http://www.lcf.dk/rig-pa-nisser/) 
Hvis tungtleddet er tilstrækkelig tungt, som i (28a), vil det være unaturligt at vente med et eventuelt ekstraponeret led til efter tungtleddet:

(28b) ?? de var så livagtige at min bror og jeg troede på nisser helt indtil vi skulle konfirmeres, de historier

En endegyldig placering af tungtledspositionen relativt før ekstrapositionspladsen er der altså ikke empirisk belæg for. En lignende kritik formuleres i en fodnote i Togeby (2003), dog i et lidt andet perspektiv:

Nogle steder fremstilles Diderichsens sætningsskema med et tungtledsfelt (T) efter A-pladsen, hvor alle sætningsformede (rolle)led placeres: $\mathrm{Han}_{F}$ havde sagt $_{V}$ til hende at han ikke kom ${ }_{T}$. Det er nok rigtigt at der er en tendens til at tunge led placeres til højre, og lette led til venstre, men sætningsformede objekter står normalt før udsagnsadverbialerne - forudsat at der er tale om et udsagnsadverbial til helsætningens udsigelse og ikke ved ledsætningens: Han ville $_{v}$ skrive $_{V}$ til hende ${ }_{H(M R)}$ at han ikke kom ${ }_{E(O R)}$ fordi han ikke havde fået sagt det $t_{A}$, den anden rækkefølge er om ikke umulig, så uheldig: *? Han ville skrive til hende, fordi han ikke havde fäet sagt det, at han ikke kom. (Togeby 2003: 80)

Her er det ikke den relative placering i forhold til ekstrapositionspladsen der er problemet, men placeringen i forhold til A-pladsen, altså pladsen for frie tids- og stedsadverbialer. Uden i øvrigt at behandle tungtledsproblematikken viser Togeby at tungtled ikke $i$ alle tilfælde kommer efter eventuelle adverbielle ledsætninger. Det er værd at se nærmere på hvad der kendetegner sådanne adverbielle ledsætninger som placerer sig efter tungtleddene. Den fordi-ledsætning Togeby bruger som eksempel, svarer til hvad Hengeveld (1996) betegner som en begrundelsesledsætning, i modsætning til en årsagsledsætning:

The fuse blew because we had overloaded the circuit (årsag)

John went home because his sister would visit him (Hengeveld 1996: 128)

(begrundelse)

Hvor årsagsrelationer har rod i ydre lovmæssigheder, er begrundelser noget der eksisterer i hovedet på sprogbrugerne, og de kan derfor siges at være relationer af højere orden, jf. sætningsindholdets lagdeling (Dik et al. 1990; 
Hengeveld 1996; Hansen \& Heltoft 2011). Denne semantiske forskel spiller en rolle for ledsætningernes placeringsmuligheder. I modsætning til Togebys begrundelsesledsætning kan en årsagsledsætning med fordi således uden problemer placeres før en tungtledsplaceret at-ledsætning:

(31) vejen var så glat fordi det regnede, at bilerne skøjtede rundt på tværs af kørebanerne

Disse observationer kan hjælpe med at indkredse tungtleddenes placering, nemlig tilsyneladende et sted mellem adverbialer der udtrykker relationer af lavere orden - ud over årsag drejer det sig fx om tid og sted - og adverbialer der udtrykker relationer af højere orden, fx begrundelser og illokutionære tilføjelser. En dækkende karakteristik af disse rækkefølgerelationer kræver dog at også ekstraposition og interjektionalposition inddrages, hvorfor de er udgangspunktet i den videre diskussion.

\section{Et forsøg på et topologisk skelet for den yderste højrefløj}

4.1. Ekstraponerede led og interjektionaler

Ekstraposition defineres hos Hansen \& Heltoft som "... en konstruktion hvor et led med funktion inden for en setning placeres uden for denne satnings normale placeringsramme." (Hansen \& Heltoft 2011 : 1827). Om ekstrapositionen til højre skriver Hansen \& Heltoft at det ekstraponerede led som hovedregel er placeret sidst i sætningen, men at det også kan stå "... umiddelbart efter setningskernen, altså efter valensleddene og for evt. adverbier...” (Hansen \& Heltoft 2011: 1833), fx:

(32a) den bliver jo ødelagt på den måde, låsen

(32b) den bliver jo ødelagt, låsen, på den måde (Hansen \& Heltoft 201 1: 1833)

Skematisk præsenterer de placeringsmulighederne således:

\begin{tabular}{llll} 
& $\mathbf{E}$ & FA & E \\
\hline hvis den falder på gulvet, & vasen, & i kampens hede & \\
\hline hvis den falder på gulvet & & i kampens hede, & vasen \\
\hline
\end{tabular}

Figur 2. Final ekstraposition hos Hansen Ë Heltoft (2011: 1841). 
Endnu længere til højre - i et "ytrings-" eller "diskursskema" (Hansen \& Heltoft 2011: 1621) - findes interjektionalpositionen (Heltoft 1990; Hansen \& Heltoft 2011), som bl.a. huser bestemte interjektioner (fx altså, okay, ja, nej, mand) og parentetiske led (fx faktisk, ikke?, jo, sgu, synes jeg, kan man sige):

Interjektionaler står alleryderst, egentlig uden for sætningen, enten til venstre eller til højre.

gud, afstemningen er sluttet for en halv time siden

du har vel husket at stemme, ikke?

Deres yderposition ses af at de kan stå uden for endog ekstraposition. (Hansen \& Heltoft 2011: 1621)

Interjektionalpositionerne og ekstrapositionerne placerer sig altså som i figur 4 med udgangspunkt i Hansen \& Heltofts skema, hvor jeg har givet betegnelserne $\mathrm{E}_{\mathrm{h} 1}$ og $\mathrm{E}_{\mathrm{h} 2}$ til ekstrapositionerne hhv. før og efter de frie adverbialer:

\begin{tabular}{|c|c|c|c|c|c|c|c|c|c|c|}
\hline $\mathbf{I}_{\mathbf{v}}$ & $\mathbf{E}_{\mathrm{v}}$ & F & V & $\mathrm{N}$ & DO & $\mathrm{P}$ & $\mathbf{E}_{\mathrm{h} 1}$ & FA & $\mathbf{E}_{\mathrm{h} 2}$ & $\mathbf{I}_{\mathbf{h}}$ \\
\hline gud & $\begin{array}{l}\text { afstem- } \\
\text { ningen }\end{array}$ & den & er & & & slut & & $\begin{array}{l}\text { for en } \\
\text { time siden }\end{array}$ & & ikke? \\
\hline gud & & den & er & & & slut & & $\begin{array}{l}\text { for en } \\
\text { time siden }\end{array}$ & $\begin{array}{l}\text { afstem- } \\
\text { ningen }\end{array}$ & ikke? \\
\hline gud & & den & er & & & slut & $\begin{array}{l}\text { afstem- } \\
\text { ningen }\end{array}$ & $\begin{array}{l}\text { for en } \\
\text { time siden }\end{array}$ & & ikke? \\
\hline
\end{tabular}

Figur 3. Interjektional- og ekstraposition hos Hansen \& Heltoft.

Imidlertid er der - som også eksemplificeret i Kristensen (2007: 67) - ikke empirisk belæg for at sige at den højrestillede interjektionalposition befinder sig efter ekstrapositionerne; vi finder også den omvendte rækkefølge:

(33) og hun var jo helt opslidt ik' den stakkels kone ik' $(\text { BySoc })^{4}$

4 Et åbent online talesprogskorpus, jf. http://bysoc.dyndns.org/index.cgi. 
(34) Ja, han siger jo ikke noget, Bethany ikke har sagt, kan man sige, ham den lækre Frederik, der er gæsteredaktør i dagens MetroXpress ovre hos Jonas Kæmpelækker Rathje (www.facebook.com/BitterfissenBethany)

Hansen \& Heltoft nævner faktisk også at $\mathrm{I}_{\mathrm{h}}$ endog kan komme før "tungtledsfeltet" ${ }^{\prime \prime}$ (Hansen \& Heltoft 2011: 1622), om end det (autentiske) eksempel de giver, er vanskeligt at tolke:

ja det er sådan ja har der været noget af det (Hansen \& Heltoft 2011: 1622)

Det er dog ikke svært at finde tilsvarende eksempler, idet det bl.a. er muligt at indskyde interjektionale parentetiske led før tungtledsplacerede nominale ledsætninger, fx:

(36) Alle disse faktorer betyder, tror jeg, at priserne ikke kommer højere op i realpriser. (http://www.amino.dk/forums/t/117075.aspx)

Også ekstrapositionen kan findes længere fremme i sætningen, fx:

$$
\begin{aligned}
& \text { han boede min kæreste på M } \% \% \% \% \% \% \% \% \% \% \% \% \% \text { på det tids- } \\
& \text { punkt }
\end{aligned}
$$
(BySoc)

Det er med andre ord vanskeligt at opstille absolutte positioner og en fast indbyrdes rækkefølge for de højrestillede ekstraponerede led og interjektionaler. De har såkaldt tetiske træk (Kaltenböck et al. 2011; Boye \& Harder 2015) og har kun partielt grammatikaliseret topologi. Ikke desto mindre vil jeg vise at der findes strukturelt belæg for rækkefølgen $\mathrm{E}_{\mathrm{h}} \rightarrow \mathrm{I}_{\mathrm{h}}$ når analysen sættes $\mathrm{i}$ relation til tungtleddenes nærmere topologi.

5 Betegnelsen 'tungtledsfelt' bruger Hansen \& Heltoft ikke generelt (typisk 'tungtledsplacering'), en forskel jeg ikke tillægger nærmere betydning. 


\subsection{Tungtled og illokutionare ledsatninger}

Som eksemplificeret i afsnit 3.2. ser tungtledspositionen ud til at være lokaliseret mellem positionerne for to forskellige slags adverbielle ledsætninger, mere specifikt - med Hansen \& Heltofts terminologi (2011: 1541) - efter eventuelle propositionelle ledsætninger, og før eventuelle illokutionœre ledsætninger. Førstnævnte er kendetegnet ved at de er del af oversætningens propositionelle indhold, mens sidstnævnte "... markerer satningens subjektive og illokutionare tolkningsrammer." (Hansen \& Heltoft 2011: 1541). Groft opdelt er den tidligere diskuterede årsags-fordi-ledsætning således at betragte som propositionel, mens begrundelses-fordi-ledsætningen er illokutionær. Dette skel er også relevant for en række andre adverbielle ledsætningstyper (for en oversigt se fx Mortensen 2011, 2013), herunder temporale ledsætninger og deres ikke-temporale modstykker, fx:
(38a) jeg har fået ny cykel siden vi sidst mødtes (temporal, propositionel)
(38b) jeg har fået ny cykel, siden du spørger (ikke-temporal, illokutionær)

I figur 4 nedenfor ses konstruerede eksempler med temporale og ikke-temporale ledsætninger indledt af hhv. siden, mens og når. Eksemplerne illustrerer at de illokutionære ledsætninger ikke - eller kun som parentetiske indskud - kan stå til venstre for tungtleddene, jf. (39b), (40b) og (41b). Her kan de propositionelle, rent temporale ledsætninger derimod placeres uden problemer, jf. (39c), (40c) og (41c): 


\begin{tabular}{|c|c|c|c|c|}
\hline & $\begin{array}{l}\text { Fundament-, } \\
\text { kernefelt mv. }\end{array}$ & $\begin{array}{l}\text { Propositionelle } \\
\text { ledsætninger }\end{array}$ & Tungtled & $\begin{array}{l}\text { Illokutionære } \\
\text { ledsætninger }\end{array}$ \\
\hline (39a) & $\begin{array}{l}\text { Jeg har gået og } \\
\text { håbet }\end{array}$ & & $\begin{array}{l}\text { at hun } \\
\text { ville ringe }\end{array}$ & $\begin{array}{l}\text { siden hun nu } \\
\text { virkede så } \\
\text { interesseret }\end{array}$ \\
\hline$(39 b)$ & $\begin{array}{l}\text { Jeg har gået og } \\
\text { håbet }\end{array}$ & $\begin{array}{l}\text { ?? siden hun nu } \\
\text { virkede så } \\
\text { interesseret }\end{array}$ & $\begin{array}{l}\text { at hun } \\
\text { ville ringe }\end{array}$ & \\
\hline$(39 c)$ & $\begin{array}{l}\text { Jeg har gået og } \\
\text { håbet }\end{array}$ & siden vi sås & $\begin{array}{l}\text { at hun } \\
\text { ville ringe }\end{array}$ & $\begin{array}{l}\text { siden hun nu } \\
\text { virkede så } \\
\text { interesseret }\end{array}$ \\
\hline (40a) & $\begin{array}{l}\text { Jens havde } \\
\text { besluttet }\end{array}$ & & $\begin{array}{l}\text { at tage } \\
\text { kampen } \\
\text { op }\end{array}$ & $\begin{array}{l}\text { mens Ole ikke var } \\
\text { helt så kæphøj }\end{array}$ \\
\hline$(40 b)$ & $\begin{array}{l}\text { Jens havde } \\
\text { besluttet }\end{array}$ & $\begin{array}{l}\text { ?? mens Ole ikke var } \\
\text { helt så kæphøj }\end{array}$ & $\begin{array}{l}\text { at tage } \\
\text { kampen } \\
\text { op }\end{array}$ & \\
\hline$(40 c)$ & $\begin{array}{l}\text { Jens havde } \\
\text { besluttet }\end{array}$ & $\begin{array}{l}\text { mens adrenalinen } \\
\text { pumpede }\end{array}$ & $\begin{array}{l}\text { at tage } \\
\text { kampen } \\
\text { op }\end{array}$ & $\begin{array}{l}\text { mens Ole ikke var } \\
\text { helt så kæphøj }\end{array}$ \\
\hline (41a) & $\begin{array}{l}\text { De køber nok } \\
\text { den cykel (til } \\
\text { mig) }\end{array}$ & & $\begin{array}{l}\text { som jeg } \\
\text { ønsker } \\
\text { mig }\end{array}$ & $\begin{array}{l}\text { når nu jeg ingen } \\
\text { julegave fik }\end{array}$ \\
\hline (41b) & $\begin{array}{l}\text { De køber nok } \\
\text { den cykel (til } \\
\text { mig) }\end{array}$ & $\begin{array}{l}\text { ?? når nu jeg ingen } \\
\text { julegave fik }\end{array}$ & $\begin{array}{l}\text { som jeg } \\
\text { ønsker } \\
\text { mig }\end{array}$ & \\
\hline$(41 c)$ & $\begin{array}{l}\text { De køber nok } \\
\text { den cykel (til } \\
\text { mig) }\end{array}$ & når vi skal i Field's & $\begin{array}{l}\text { som jeg } \\
\text { ønsker } \\
\text { mig }\end{array}$ & $\begin{array}{l}\text { når nu jeg ingen } \\
\text { julegave fik }\end{array}$ \\
\hline
\end{tabular}

Figur 4. Illokutionere ledsetninger efter hhv. for tungtledsposition.

Tungtledspositionen befinder sig altså før positionen for illokutionære ledsætninger. På positionen for illokutionære ledsætninger findes i øvrigt også alle andre slags finale ledsætninger der ikke indgår i oversætningens propositionelle indhold, herunder konnektive ledsætninger indledt af fx ligesom (at), samtidig med at, hvor (at), hoorimod (at) og plus (at) (Hansen \& Heltoft 2011: 1554) og relativsætninger med sætningen eller dens prædikation som korrelat, fx hvorfor-, hvorefter-, hvormed-, hvorpå-, hvorved-, hvilket og hvad-ledsætninger. ${ }^{6}$

6 Se også Mortensen (2011), hvor ledsætningstyper med denne placering klassificeres som appendix clauses. 


\subsection{Tungtled og propositionelle ledsatninger}

Mindre entydig er rækkefølgen mellem tungtleddene og de propositionelle ledsætninger. Vi kan nemlig uden videre bytte rundt på de temporale ledsætninger og den tunge at-ledsætning, at-infinitiv og som-relativsætning fra figur 4:

(39d) Jeg har gået og håbet at hun ville ringe, siden vi sås

(40d) Jens havde besluttet at tage kampen op, mens adrenalinen pumpede (41d) De køber nok den cykel til mig som jeg ønsker mig, når vi skal i Field's

Dette åbner for to forskellige beskrivelsesstrategier, illustreret ved eksempel (39d) i figur 5 nedenfor: Enten betragter vi fortsat at-ledsætningen som tungtledsplaceret, hvorved siden-ledsætningen tillige må betragtes som tungtledsplaceret; eller også placerer vi siden-ledsætningen på pladsen for frie led (her slået sammen med middelbare led) og at-ledsætningen dermed fremme i kernefeltet:

\begin{tabular}{|c|c|c|c|c|}
\hline & $\begin{array}{l}\text { Fundament- og } \\
\text { kernefelt }\end{array}$ & $\begin{array}{l}\text { Frie og } \\
\text { middelbare } \\
\text { led }\end{array}$ & Tungtled & $\begin{array}{l}\text { Illokutionær } \\
\text { ledsætning }\end{array}$ \\
\hline \multirow[t]{2}{*}{ (39d) } & $\begin{array}{l}\text { Jeg har gået og } \\
\text { håbet }\end{array}$ & & $\begin{array}{l}\text { at hun ville } \\
\text { ringe, siden vi } \\
\text { sås }\end{array}$ & \\
\hline & $\begin{array}{l}\text { Jeg har gået og } \\
\text { håbet at hun ville } \\
\text { ringe }\end{array}$ & siden vi sås & & \\
\hline
\end{tabular}

Figur 5. Beskrivelsesstrategier for temporal ledsatning efter at-ledsetning.

Muligheden for at indsætte $\mathrm{fx}$ et adverbielt led før $a t$-ledsætningen taler for at den hører til i tungtledspositionen:

(39e) Jeg har gået og håbet i al hemmelighed at hun ville ringe, siden vi sås

Hansen \& Heltoft giver eksempler på at at-infinitiver og objektledsætninger ikke nødvendigvis behøver stå i tungtledsposition, men kan placeres i kernefeltet for eksempelvis at lede fokus hen på efterfølgende middelbare eller frie led: 
(40a) man har tilbudt at sælge for to minutter siden (Hansen \& Heltoft 2011: 1644)

(41a) jeg hørte at du var kommet, fra min søster

(42a) jeg hørte at du kom, i morges

(Hansen \& Heltoft 2011: 1643)

Hansen \& Heltofts analyse understøttes af at fokusstrukturen gør det vanskeligt at indsætte $\mathrm{fx}_{\mathrm{x}}$ frie led og dermed fremtvinge en tungtledslæsning - der bliver konkurrence om at tiltrække fokus, og det resulterer i informationsstrukturelt tvetydige sætninger:

(40b) ? man har tilbudt lidt uovervejet at sælge for to minutter siden (41b) ? jeg hørte i går at du var kommet, fra min søster (42b) ? jeg hørte som den første at du kom, i morges

Men denne fokustvetydighed synes at blive mindsket - så at sige overdøvet af vægtprincippet - hvis man udskifter Hansen \& Heltofts efterfølgende led med fulde adverbielle ledsætninger:

(40c) man har tilbudt lidt uovervejet at sælge efter tallene er blevet offentliggjort

(41c) jeg hørte i går at du var kommet, da jeg talte med min søster

(42c) jeg hørte som den første at du kom, mens jeg sad og slubrede morgenkaffen i mig

Der er altså en tendens til at relativt lette frie og middelbare led insisterer på deres normale pladser før tungtledspositionen, mens fulde adverbielle ledsætninger mere frit kan placeres før eller efter fx tunge at-ledsætninger. Forskellen er illustreret skematisk i figur 6: 


\begin{tabular}{lll}
$\begin{array}{l}\text { Fundament- og } \\
\text { kernefelt }\end{array}$ & $\begin{array}{l}\text { Frie og } \\
\text { middelbare led }\end{array}$ & Tungtled \\
\hline Jeg har gået og håbet & siden i går & at hun ville ringe \\
\hline $\begin{array}{l}\text { Jeg har gået og håbet at } \\
\text { hun ville ringe }\end{array}$ & siden i går & \\
\hline ? Jeg har gået og håbet & i al hemmelighed & $\begin{array}{l}\text { at hun ville ringe, siden i } \\
\text { går }\end{array}$ \\
\hline Jeg har gået og håbet & i al hemmelighed & $\begin{array}{l}\text { at hun ville ringe, siden vi } \\
\text { sås }\end{array}$ \\
\hline
\end{tabular}

Figur 6. Propositionelle ledsatninger i tungtledsposition.

\subsection{Ud med tungtledspositionen, ind med ledsatningsfeltet}

Tungtledspositionen er ikke kun en "lidt litterær eller gammeldags" (Hansen 2007: 65) særplacering af specielle tunge led, men snarere en regulær position i sætningsskemaet, hvor mange nominale, adverbielle og relative ledsætninger, at-infinitiver og andre komplekse led normalt vil ophobes. Fælles for dem er bl.a. at de er del af oversætningens propositionelle indhold, så lidt generaliserende kan positionen lige så vel beskrives som en plads for (finale) propositionelle ledsætninger (mv.) som den kan kaldes en tungtledsposition. Denne plads kan endvidere kobles sammen med nabopladsen for illokutionære ledsætninger, hvorved en generalisering til slet og ret ledsetningsfelt kan have sin - i hvert fald pædagogiske - berettigelse, om end feltet altså også rummer andet end ledsætninger. Eksempler af forskellige slags ses i figur 7: 


\begin{tabular}{|c|c|c|c|}
\hline \multirow[b]{2}{*}{$\begin{array}{l}\text { Fundament- } \\
\text { og kernefelt }\end{array}$} & \multirow[b]{2}{*}{$\begin{array}{l}\text { Frie og } \\
\text { middelbare } \\
\text { led }\end{array}$} & \multicolumn{2}{|c|}{ Ledsatningsfelt } \\
\hline & & $\begin{array}{l}\text { Propositionelle } \\
\text { ledsætninger mv. }\end{array}$ & $\begin{array}{l}\text { Illokutionære } \\
\text { ledsætninger }\end{array}$ \\
\hline $\begin{array}{l}\text { Jeg har gået } \\
\text { og håbet }\end{array}$ & & $\begin{array}{l}\text { at hun ville ringe, } \\
\text { siden vi sås }\end{array}$ & $\begin{array}{l}\text { selvom det kun var } \\
\text { et kort møde }\end{array}$ \\
\hline $\begin{array}{l}\text { Jens havde } \\
\text { besluttet }\end{array}$ & & $\begin{array}{l}\text { mens adrenalinen } \\
\text { pumpede, at tage } \\
\text { kampen op }\end{array}$ & $\begin{array}{l}\text { fordi hvem skulle } \\
\text { ellers gøre det? }\end{array}$ \\
\hline $\begin{array}{l}\text { De køber nok } \\
\text { den cykel }\end{array}$ & til mig & som jeg ønsker mig & $\begin{array}{l}\text { hvilket ville være } \\
\text { fantastisk }\end{array}$ \\
\hline $\begin{array}{l}\text { Lidt efter var } \\
\text { (der) forsamlet }\end{array}$ & i den store Sal & $\begin{array}{l}\text { en talrig Skare af } \\
\text { Generaler og } \\
\text { højtstaaende } \\
\text { Embedsmænd }\end{array}$ & $\begin{array}{l}\text { plus at dronningen } \\
\text { vist også var der! }\end{array}$ \\
\hline $\begin{array}{l}\text { Jeg hørte at } \\
\text { du var } \\
\text { kommet }\end{array}$ & fra min søster & & $\begin{array}{l}\text { hvis du skulle være } \mathrm{i} \\
\text { tvivl }\end{array}$ \\
\hline $\begin{array}{l}\text { Vi var så } \\
\text { trætte }\end{array}$ & $\begin{array}{l}\text { efter } \\
\text { biograffilmen }\end{array}$ & & \\
\hline $\begin{array}{l}\text { Vi var så } \\
\text { trætte }\end{array}$ & & efter filmen var slut & \\
\hline $\begin{array}{l}\text { Vi var så } \\
\text { trætte }\end{array}$ & & $\begin{array}{l}\text { efter filmen var slut, } \\
\text { at vi tog en taxa hjem }\end{array}$ & \\
\hline
\end{tabular}

Figur 7. Skema med ledsetningsfelt og diverse eksempler.

\subsection{Ekstraposition, interjektionalposition og ledsatningsfelt}

Analysen kan nu inddrage placeringen af ekstraponerede led og interjektionaler. Jeg viste i afsnit 4.1. at disse størrelser er vanskelige at tildele egentlige pladser, da de kan optræde flere forskellige steder i sætningen og i forskellig rækkefølge. Dog kan analysen af ledsætningsfeltet være med til at belyse at de har topologiske restriktioner, idet der synes at være forskel på hvor langt tilbage i sætningen hhv. ekstraponerede led og interjektionaler kan optræde. For eksempel kan det ekstraponerede led ham Boris i de følgende eksempler stå før at-ledsætningen og efter at-ledsætningen, men ikke efter selvom-ledsætningen: 
(43a) Han påstod jo den morgen, ham Boris, at hun var syg, selvom ingen rigtig troede på det

(43b) Han påstod jo den morgen at hun var syg, ham Boris, selvom ingen rigtig troede på det

(43c) * Han påstod jo den morgen at hun var syg, selvom ingen rigtig troede på det, ham Boris

Derimod kan interjektionalet ik' stå i de samme positioner, og desuden også efter selvom-ledsætningen:

(43d) Han påstod jo den morgen, ik', at hun var syg, selvom ingen rigtig troede på det

(43e) Han påstod jo den morgen at hun var syg, ik', selvom ingen rigtig troede på det

(43f) Han påstod jo den morgen at hun var syg, selvom ingen rigtig troede på det, ik'

Dette hænger antagelig sammen med at ekstraponering er en referentiel relation som vanskeligt kan række ud over den proposition den hører til. Interjektionaler er derimod i stand til at operere på sætningens illokutionære lag og kan derfor - i nogle tilfælde og for nogles vedkommende - få skopus over selv illokutionære ledsætninger. Figur 8 herunder giver et par yderligere eksempler på denne forskel. Bemærk at ekstrapositionen og interjektionalpositionen ikke kan udpeges absolut, da de begge kan optræde flere steder længere fremme i sætningen, og i begge rækkefølger. Til gengæld kan de repræsenteres ved deres sidste mulige placering, hvilket de bagudrettede pile $\mathrm{i}^{\prime}<\mathrm{E}_{\mathrm{h}}{ }^{\prime} \mathrm{Og}$ ' $<\mathrm{I}_{\mathrm{h}}$ ' indikerer, hvorved den indbyrdes rækkefølge som Hansen \& Heltoft peger på, jf. afsnit 4.1., har sin berettigelse. 


\begin{tabular}{|c|c|c|c|c|}
\hline \multirow[b]{2}{*}{$\begin{array}{l}\text { Satningens } \\
\text { begyndelse }\end{array}$} & \multicolumn{3}{|c|}{ Ledsætningsfelt } & \multirow[b]{2}{*}{$<\mathbf{I}_{\mathbf{h}}$} \\
\hline & $\begin{array}{l}\text { Propositionelle } \\
\text { ledsætninger mv. }\end{array}$ & $<\mathbf{E}_{\mathbf{h}}$ & $\begin{array}{l}\text { Illokutionære } \\
\text { ledsætninger }\end{array}$ & \\
\hline Han tog hjem & $\begin{array}{l}\text { da hun dukkede } \\
\text { op }\end{array}$ & ham Bori & & \\
\hline Han tog hjem & & & $\begin{array}{l}\text { da hun aldrig } \\
\text { dukkede op }\end{array}$ & $\begin{array}{l}\text { faktisk } \\
\text { *ham Boris }\end{array}$ \\
\hline $\begin{array}{l}\text { Har I boet her i } \\
\text { Taastrup }\end{array}$ & $\begin{array}{l}\text { siden han blev } \\
\text { født }\end{array}$ & $\begin{array}{l}\text { du og } \\
\text { Mia }\end{array}$ & & \\
\hline $\begin{array}{l}\text { Har I boet her i } \\
\text { Taastrup }\end{array}$ & & & $\begin{array}{l}\text { siden vi kører den } \\
\text { vej }\end{array}$ & $\begin{array}{l}\text { egentlig } \\
\text { *du og Mia }\end{array}$ \\
\hline $\begin{array}{l}\text { Er det så vigtigt } \\
\text { for hende }\end{array}$ & $\begin{array}{l}\text { at komme på } \\
\text { internettet }\end{array}$ & $\begin{array}{l}\text { din } \\
\text { kæreste }\end{array}$ & & \\
\hline $\begin{array}{l}\text { Er det så vigtigt } \\
\text { for hende }\end{array}$ & $\begin{array}{l}\text { at komme på } \\
\text { internettet }\end{array}$ & & $\begin{array}{l}\text { selvom vi er på } \\
\text { landet }\end{array}$ & $\begin{array}{l}\text { hva' } \\
\text { *din kæreste }\end{array}$ \\
\hline
\end{tabular}

Figur 8. Samlet skema for satningsperiferien, med diverse eksempler.

\section{Afrunding}

Jeg har peget på at flere typer ledsætninger end man normalt nævner i grammatikfremstillingerne, må være tungtledsplacerede når man applicerer de gængse kriterier på deres konstruktioner. Derudover har jeg prøvet at indkredse hvor tungtledsplaceringen mere specifikt befinder sig i sætningen, og vist at den befinder sig til venstre for en position forbeholdt illokutionære ledsætninger. I den forbindelse har jeg illustreret muligheden for at generalisere de forskellige finale positioner for ledsætninger, at-infinitiver og særlige tungtled til et samlet 'ledsætningsfelt', der i de fleste tilfælde overflødiggør den problematiske tungtledsplacering som topologisk kategori. Endelig har et afkast af disse analyser været præciseringen af hvor ekstra- og interjektionalpositionerne er lokaliseret, nemlig senest før hhv. efter de illokutionære ledsætninger. Tilsammen kan disse positionsundersøgelser supplere de eksisterende sætningsskemaer og forhåbentlig være med til at rydde lidt op på den yderste højrefløj. ${ }^{7}$

7 Tak til Lars Heltoft, Peter Juul Nielsen, redaktør Jan Heegård Petersen og en anonym fagfællebedømmer for værdifulde kommentarer til foreløbige versioner af dette bidrag. 


\section{Henvisninger}

Becker-Christensen, G. (2010). Dansk syntaks. 1. udg. Frederiksberg: Samfundslitteratur.

Boye, K. \& P. Harder (2015). Komplekse sætninger, tetiske udtryk og grammatikalisering, i S.E. Bentsen, et al. (red.) Ny forskning i grammatik 22, 41-58.

Christensen, L.H. \& R.Z. Christensen (2014). Dansk grammatik. 3. udg. Odense: Syddansk Universitetsforlag.

Diderichsen, P. (1946). Elementer dansk grammatik. København: Nordisk Forlag. Diderichsen, P. (1957). Elementer dansk grammatik. 2. udg. København: Gyldendal. Dik, S.C., et al. (1990). The hierarchical structure of the clause and the typology of adverbial satellites, i A.M. Bolkestein, J. Nuyts \& C. Vet (red.) Layers and levels of representation in language theory: A functional view, Amsterdam/ Philadelphia: John Benjamins Publishing Company, 25-70.

Hansen, E. (1970). Sætningsskema og verbalskemaer, $\mathcal{N} y$ S 2(2), 116-141.

Hansen, E. (2007). Demonernes port: Materiale til studiet af dansk sprog. 5. udg. København: Hans Reitzel.

Hansen, E. \& L. Heltoft (2011). Grammatik over det Danske Sprog. København \& Odense: Det Danske Sprog- og Litteraturselskab \& Syddansk Universitetsforlag.

Heltoft, L. (1986). Topologi og syntaks. En revision af Paul Diderichsens sætningsskema, NyS 16/17, 105-130.

Heltoft, L. (1990). En plads til sprogvidenskabens hittebørn: Om talesprog og sætningsskema, i Selskab for Nordisk Filologi - årsberetning 1987-1989, København: Selskab for Nordisk Filologi, 26-45.

Hengeveld, K. (1996). The internal structure of adverbial clauses, i B. Devriendt, L. Goossens \& J. van der Auwera (red.) Complex structures: A functionalist perspective, Berlin: Mouton de Gruyter, 119-148.

Jensen, A. (2003). Clause linkage in spoken Danish. Ph.d.-afhandling, Københavns Universitet.

Jensen, T.J. \& T.K. Christensen (2013). Promoting the demoted: The distribution and semantics of "main clause word order" in spoken Danish complement clauses, Lingua 137, 38-58.

Jørgensen, H. (2000). Indforing i Dansk Syntaks. 3. forel. udg. Århus: Århus Universitet.

Kaltenböck, G., B. Heine \& T. Kuteva (2011). On thetical grammar, Studies in Language 35(4), 852-897.

Kristensen, L.B. (2007). Slutfordobling i dansk talesprog. Speciale, Københavns Universitet. 
Mikkelsen, K. (1975). Dansk ordföjningslare: Med sproghistoriske tilleg: Håndbog for viderekomne og lerere. København: Hans Reitzels Forlag.

Mortensen, S.S. (2011). A distributional approach to functional Danish subclause classification, Acta Linguistica Hafniensia 43(2), 127-175.

Mortensen, S.S. (2013). Klassifikation af ledsatninger i dansk. Ph.d.-afhandling, Københavns Universitet.

Togeby, O. (2003). Fungerer denne satning? Funktionel dansk sproglere. København: Gads Forlag. 